\title{
Salinization Processes and Quality Constrains for Irrigation Water Management in Southwest El Minia, Upper Egypt.
}

\author{
M.A. Sadek, R. A. Hussien*, H. B. Hassan \\ Egyptian Nuclear and Radiological Regulatory Authority (ENRRA) \\ *Corresponding Authors: R. A. Hussien, Egyptian Nuclear and Radiological Regulatory Authority \\ (ENRRA)
}

\begin{abstract}
The present work is devoted to determine sources of groundwater salinity and quality constrains for irrigation water management in the southwest of El Minia Governorate, Upper Egypt. Hydrochemical and multivariate statistical analysis using results of major ions analysis of 67 groundwater samples collected from the study area have been conducted in this work. TDS and major ionic concentrations vary in considerably wide ranges, these increase westward and northward under effect of rock minerals dissolution and upward leakage of saline water. Analytic Hierarchy Process (AHP), which is one of the methods of Multi Criteria Decision Approach (MCDA) for development a new water quality index is used, it combines eight of the water quality controlling parameters that complementarily express the whole scale of irrigation water quality hazards on soils and plants. The application of the developed irrigation suitability index on the results of collected groundwater samples analysis reflected a significant hazards related to water salinity and quality attributes. The soil salinity degradation and potential yield reduction on typical crops in the study area have been described. The leaching requirements of soil salinity have been determined for management of irrigation water quality.
\end{abstract}

Keywords: Groundwater Quality, Multivariate Analysis, AHP/MCDA, WQI, Leaching Requirements, El Minia Egypt

\section{INTRODUCTION}

Sustainable groundwater management has become one of the biggest challenges to cover the demands of present day and future development programs (agricultural, urban, industrial, .etc.). Groundwater management (both quantitative and qualitative) is constrained by recharge, discharge, flow and quality regimes, it seeks a renewal/withdrawal balance and quality degradation retreat (the qualitative terms of groundwater management is the subject of the present work). Deterioration of groundwater quality falls into two broad categories; that due to natural conditions and that due to anthropogenic causes, (Jakeman et al 2016). Extraction or changes to recharge can alter groundwater flow directions or expose aquifer material to natural contaminants such salt and some trace elements and resulting in poor water quality and associated health impacts (Sadek et al, 2020a). The overexploitation of groundwater may cause upconing of saline deep water or inland invasion of sea water. The contact of water with rock matrix along transit and residence may rise salinity by leaching, dissolution, ion exchange... etc. The solutes and trace elements content of water determine its suitability for different uses and the way to manage hazards due to that. Egypt, to face the exceeding shortage of water resources while population rate progressively increases and standards of living rises, has launched a strategic plan to accommodate the water and food deficit by extension of agricultural lands to the desert areas which are located at the periphery of traditionally cultivated lands in the Nile Delta and Valley. Groundwater resources of adequate quantity and quality is primarily required to meet the needs of desert reclamation and agricultural expansion in the remote areas away from Nile River and irrigation canals network. This necessitates a detailed investigation and exploration of the hydro geologic system of the allocated area. Several works have been conducted in the area under study and its surroundings (southwest El Minia, upper Egypt) dealing with geological and hydrogeological conditions but in localized sporadic zones (Korany et al. 2008, Said, 1990, RIGW 1992, Tantawy 2006, Abu Heleika and Niesner 2008, El Kashouty et al 2013, Abdulaziz et al, 2017, Reda et al, 2017, Sallam et al, 2020). Recently, the concept of water quality index (WQI- 

Upper Egypt.

AHP) has been used as a powerful decision support tool in water resources management to assess the quality state of a water body modified into dimensionless numbers in a simple manner, (Zavadskas and Turskis, 2011, Sadek and Hagagg 2020b). The present work aimed at evaluation of salinity sources of the groundwater resources in south West El-Minia, Upper Egypt and to determine the quality constrains for irrigation use, also to point out an applicable method for management these constrains. This goal has been achieved through the conjugation between classical hydrochemical interpretation with the multivariate statistical analysis (MSA) to get more insight to the sources of salinity and evolution trends. In addition to that, a new water quality index (WQI) to assess the irrigation quality state of the groundwater system in the study area was developed using Analytical Hierarchy Process (AHP) of the MPDA approach. Further a suggested method for treatment and management the quality constrains of irrigation water have been recommended.

\section{Physical Setting of the Study Area}

The study area is located in mid Upper Egypt, it lies between longitudes $29^{\circ} 9^{\prime} \quad 37.41^{\prime \prime}$ and $30^{\circ} 58^{\prime}$ $5.49^{\prime} \mathrm{E}$, and latitudes of $27^{\circ} 32^{\prime} 28.13^{\prime \prime}$ and $28^{\circ} 47^{\prime} 6.36^{\prime \prime} \mathrm{N}$. Fig. (1a), it is characterized by arid to semiarid climate with hot dry summer and rare precipitation winter. The minimum temperature varies from 4.5 (January) to $20.5^{\circ} \mathrm{C}$ (August), while the maximum temperature varies from 20.7 (January) to $39.7^{\circ} \mathrm{C}$ (August). The mean monthly relative humidity during daytime ranges from $36 \%$ in May to $62 \%$ in December (Reda et al 2017). Three geomorphologic units appear in the study area (Fig 1c), from east to west (young alluvial plain, old alluvial plain and plateau). The young alluvial plain bounds the Nile River and is filled with Holocene silt and clay, it is followed westward by old alluvial plain unit which is covered by Pleistocene sands and gravels and the lower Eocene Plateau.
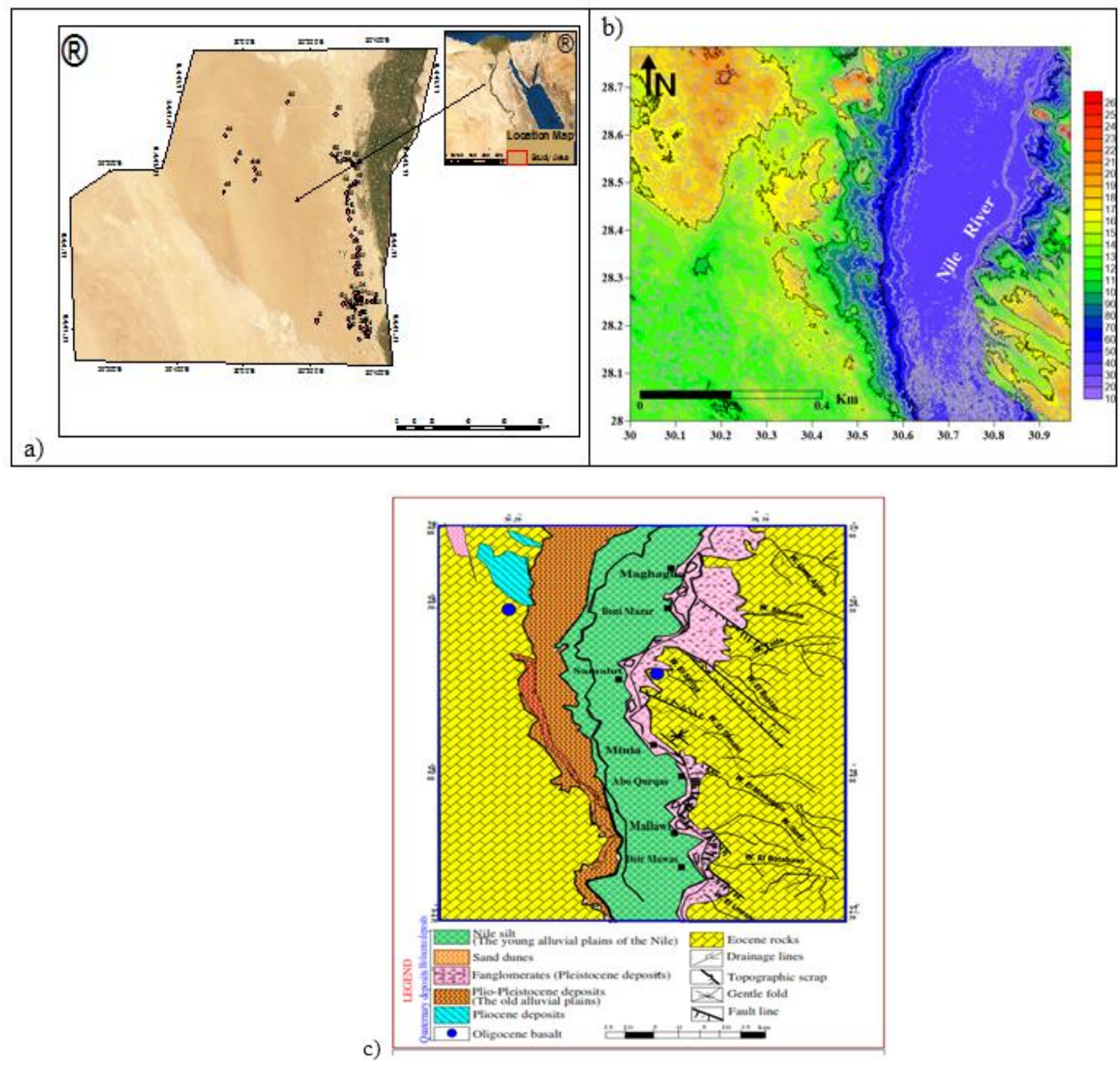

Fig1. a) Well location map of the study area; b) Digital Elevation Model (DEM); c) geomorphological and geologic map of El Minia district (Conoco Coral Egypt 1987 and modified by Abou Heleika and Niesnr (2008) and Kamel (2012). 
Litho-stratigraphically, the following layers have been identified in the work of (Abu Heleika and Niesner 2008) and described by (El Kashouty, 2013): (a) The Quaternary deposits that are formed of Pleistocene sands and gravels intercalated with clay lenses capped by Holocene Nile Silt and Clay. (b) The Pliocene clay beds that become absent in the north and west (c) The Eocene limestone which is differentiated into four formations; Samalut, Wadi El Rayan, El Minia and Drunka Formations). Hydrogeologically, two main aquifers are encountered in El Minia area, namely (1) the Quaternary (alluvium) aquifer which has a wide distribution in Nile Valley and the adjacent areas at the foot slope of the Eocene plateaus. This aquifer is composed mainly of coarse, thick sand and gravel beds intercalated with clay lenses. (2) The Eocene (limestone) aquifer which is the subject of this work is represented by Samalut Formation which is used for agricultural expansion in the study area. It is unconfined under the alluvium aquifer and overlies the Nubian sandstone aquifer; it occupies the extreme western sides of the study area and is affected by a network of faults, joints and fractures that may play a role in the recharge mechanism to this aquifer.

\section{Materials ANd Methods}

A set of representative 67 groundwater samples were analyzed for physical measurements including Electrical conductivity (EC), pH, temperature, total dissolved solids (TDS), using portable probes. For chemical parameters comprising major cations $(\mathrm{Ca}, \mathrm{Mg}, \mathrm{Na}, \mathrm{K})$ and anions $\left(\mathrm{Cl}, \mathrm{SO}_{4}, \mathrm{HCO}_{3}\right)$ concentrations. All the wells located in El Minia had been in use during the time of sampling (Fig.1b). The samples were collected in 1-L narrow neck pre-washed polyethylene bottles. Analysis of the water samples was carried out following the methods described in (ASTM, 2002). Total hardness $(\mathrm{TH})$ as $\mathrm{CaCO}_{3}$ and $\mathrm{Ca}^{2+}$ were analyzed using standard EDTA. $\mathrm{Mg}^{2+}$ was calculated by taking the differential value between $\mathrm{TH}$ and $\mathrm{Ca}^{2+}$ concentrations. $\mathrm{Na}^{+}$and $\mathrm{K}^{+}$were measured using a flame photometer. Total alkalinity and $\mathrm{CaCO}_{3}, \mathrm{CO}_{3}{ }^{2-}$, and $\mathrm{HCO}_{3}{ }^{-}$were estimated by titrating with $\mathrm{HCl}$. $\mathrm{Cl}^{-}$was determined by standard $\mathrm{Hg}\left(\mathrm{NO}_{3}\right)_{2}$ titration. $\mathrm{SO}_{4}{ }^{2-}$ was analyzed using a spectrophotometer. All parameters are expressed in milligrams per liter and milliequivalents per liter. Data quality was assessed using the charge balance between the difference of cations and anions (expressed in meq/l) divided by their summation according to the following equation:

$\Sigma$ (Cations- Anions) $/ \Sigma$ (Cations+ Anions) X 100

With an acceptable range of \pm 5 (Hem 1991) that confirm the water quality assessment. The results data from hydrochemical analysis have been treated, analyzed, processed using standard reference methods (graphical, mathematical and statistical) for describing the sources of salinity and evolution of the groundwater under study, as well as irrigation suitability constrains area. The Multi Criteria Decision Approach (MCDA), Analytic Hierarchy Process (AHP), (Saaty's 1980) has been applied for development a new water quality index for irrigation suitability. The standard methods have been used for determining proposed methods for management and treatment the adverse effects of irrigation water salinity.

\section{RESUltS AND DISCUSSION}

\subsection{Hydrochemical Characterization and Salinization Processes.}

The general statistics (minimum, maximum, average, standard deviation, and variation coefficient) of the chemical analyses data are shown in Table (1). The ranges of TDS and ionic species are generally wide and the coefficients of variation are significantly high $(0.79,0.89,0.92,0.78,0.75$ and 0.54 for TDS, $\mathrm{Na}, \mathrm{Cl}, \mathrm{Ca}, \mathrm{SO}_{4}$ and $\mathrm{Mg}$ respectively). This reflects less homogeneity and variability of salinization processes. The areal distribution of TDS, Fig. (2) shows a general trend of increasing concentrations from south to north with parallel increase in shale and clay content, and generally high values in the western areas (at the carbonates plateau reach). The orders of cationic and anionic concentrations of the studied groundwater samples indicated that about $83 \%$ of the samples have $\mathrm{Cl}-$ $\mathrm{Na}$ water type with two ionic orders: $\mathrm{Cl}^{-}>\mathrm{HCO}_{3}{ }^{-}>\mathrm{SO}_{4}{ }^{2-} / \mathrm{Na}^{+}>\mathrm{Mg}^{2+}>\mathrm{Ca}^{2+}$ and $\mathrm{Cl}^{-}>\mathrm{SO}_{4}{ }^{2-}>$ $\mathrm{HCO}_{3}^{-} / \mathrm{Na}^{+}>\mathrm{Mg}^{2+}>\mathrm{Ca}^{2+}$ representing $90 \%$ and $10 \%$ of the samples respectively, this Cl-Na water type and ionic orders characterize advanced stage of mineralization and potential salinization processes under effect of leaching, dissolution and exchange on surface of lithologic matrix. The water types $\mathrm{HCO}_{3}-\mathrm{Na}$ and $\mathrm{HCO}_{3}-\mathrm{Mg}$ appear in $12 \%$ and $5 \%$ of the total nos. of samples with ionic orders $\mathrm{HCO}_{3}{ }^{-}>\mathrm{Cl}^{-}>\mathrm{SO}_{4}{ }^{2-} / \mathrm{Na}^{+}>\mathrm{Mg}^{2+}>\mathrm{Ca}^{2+}$ and $\mathrm{HCO}^{-}>\mathrm{Cl}^{-}>\mathrm{SO}_{4}{ }^{2-} / \mathrm{Mg}^{2+}>\mathrm{Na}^{+}>\mathrm{Ca}^{2+}$, 
Salinization Processes and Quality Constrains for Irrigation Water Management in Southwest El Minia, Upper Egypt.

respectively, these two water types and ionic orders characterize less developed mineralization stage and dilution effects.

Table1. Descriptive Statistics of Chemical Analysis Data

\begin{tabular}{|c|c|c|c|c|c|c|}
\hline Parameters & Units & Min. & Max. & Average & SD & Var. Coefficient \\
\hline $\mathrm{pH}$ & & 6.69 & 9.2 & 8.02 & & \\
\hline $\mathrm{EC}$ & $\mu \mathrm{S} / \mathrm{cm}$ & 285 & 6880 & 1721 & 1286 & 0.73 \\
\hline TDS & $\mathrm{mg} / \mathrm{l}$ & 185 & 5160 & 1263 & 903 & 0.79 \\
\hline $\mathrm{Na}^{+}$ & $\mathrm{mg} / \mathrm{l}$ & 26 & 1220 & 249 & 209 & 0.89 \\
\hline$K^{+}$ & $\mathrm{mg} / \mathrm{l}$ & 5 & 26 & 10.14 & 6.2 & 0.62 \\
\hline$M g^{2+}$ & $\mathrm{mg} / \mathrm{l}$ & 12 & 144 & 58.3 & 31.46 & 0.54 \\
\hline $\mathrm{Ca}^{2+}$ & $\mathrm{mg} / \mathrm{l}$ & 10 & 212 & 51 & 38.48 & 0.78 \\
\hline $\mathrm{Cl}^{-}$ & $\mathrm{mg} / \mathrm{l}$ & 35 & 1714 & 405 & 361 & 0.92 \\
\hline $\mathrm{HCO}_{3}^{-}$ & $\mathrm{mg} / \mathrm{l}$ & 20 & 1033 & 147 & 159 & \\
\hline $\mathrm{SO}_{4}{ }^{2-}$ & $\mathrm{mg} / \mathrm{l}$ & 55 & 390 & 219 & 157.8 & 0.77 \\
\hline
\end{tabular}

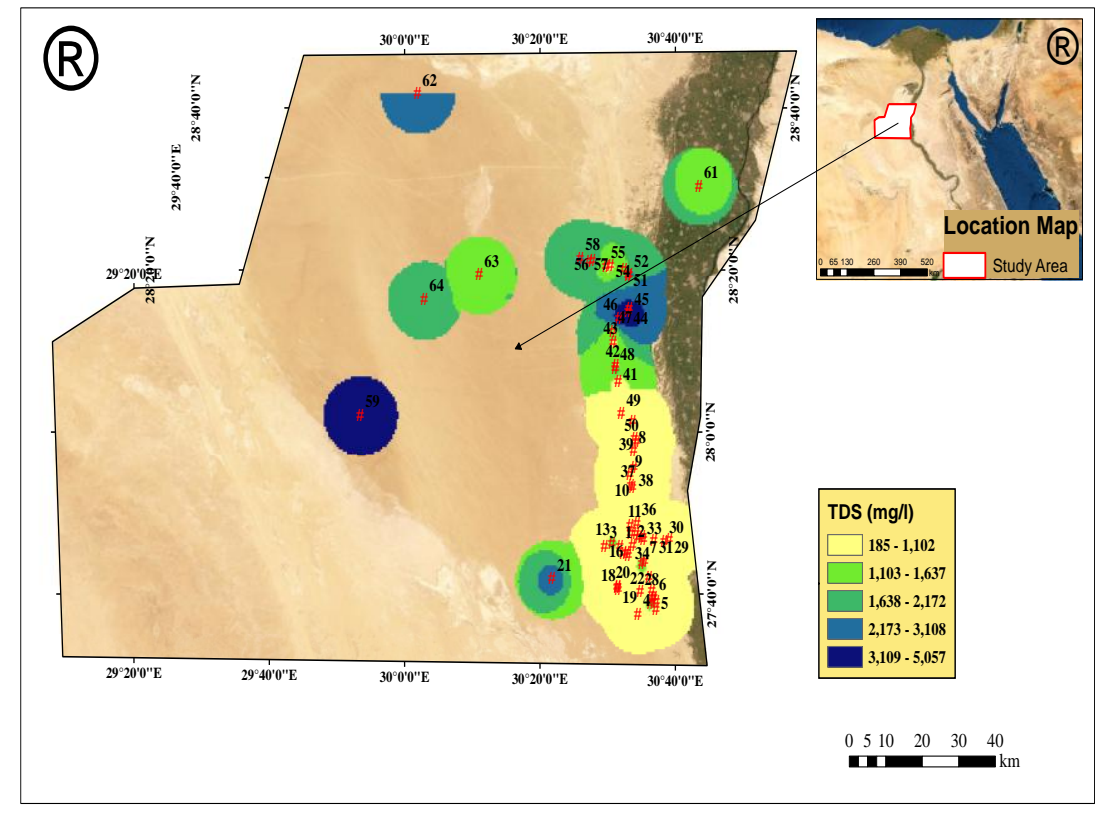

Fig2. Arial Distribution of TDS in the Study Area.

The multivariate statistical analysis is a tool used to compare and interrelate variables in the whole samples domain, accordingly classify them into groups and components representing the features and variations characterizing the system. This has been applied in the present work, in term of three items (Ionic and TDS Correlation Coefficients Matrix, Hierarchical cluster Analysis (HCA) and Principal Components Analysis (PCA ) using SPSS.22 statistical software. The correlation coefficients (C.C) matrix of TDS and major ions shows that TDS is highly corelatable to $\mathrm{Na}$ and $\mathrm{Cl}$ (C.C. $=0.98$ and 0.95 respectively), followed by $\mathrm{Mg}, \mathrm{Ca}$, and $\mathrm{SO}_{4}$ (C.C. $=0.78,0.77$. and 0.73 respectively) reflecting that salts of these ions could control groundwater salinity and quality. This is also reflected by the high C.C. between $\mathrm{Na}$ and $\mathrm{Cl}(0.94)$ and between $\mathrm{Ca}$ and $\mathrm{SO}_{4}(0.7)$ and between $\mathrm{Mg}$ and $\mathrm{Cl}(0.88)$. The hierarchical cluster analysis (HCA) is a method of classifying a set of data into two or more mutually exclusive groups, based on the combination of interval variables (Ashley and Lloyd 1978). Comparisons based on multiple parameters from different samples were made and the samples were grouped according to their similarity to each other. The output results are represented in the form of a dendrogram, Fig. (3) The studied groundwater samples have been classified according to the proximity of the water quality parameters into two major groups (A and B). Group A comprises two clusters: cluster -1 - that includes $65 \%$ of the samples and cluster -2 that includes $16 \%$ of the samples, Group B comprises two clusters: cluster - 3 that includes $13 \%$ of the samples and cluster -4 that includes samples The clustering of the samples complies with variation of TDS and ionic composition, which are controlled, by hydrogeochemical and physicochemical conditions. The hydrochemical variables that classified the samples into Dendogram groups have been analyzed 

Upper Egypt.

using Principal Components Analysis (PCA) technique to reduce the large data of these groups into a set of variables called Principal Components, Table (2), this has been done based on variances and eigenvalues relations without sacrificing much of the original information. The first two components with Eigen values $>1$ account for $82.6 \%$ of the total variance and assumed to adequately represent the overall characteristics of the data set. The first principle component (PC -1), accounts for 70.811 of the variance in the data set and combines the chemical variables TDS, $\mathrm{Cl}, \mathrm{Na}$, $\mathrm{Mg}, \mathrm{Ca}$ and SO4; the second component (PC -2) represents about $11.794 \%$ of the variance and combines HCO3 in little association with TDS and other ions. The salinization processes that could contribute to the variation of the first component parameters are evaporation, leaching/ dissolution of rock salts and ion exchange. The less association and little match of HCO3 with TDS and other ions variations in the second component could be due to dilution with rain water and Nile irrigation water.

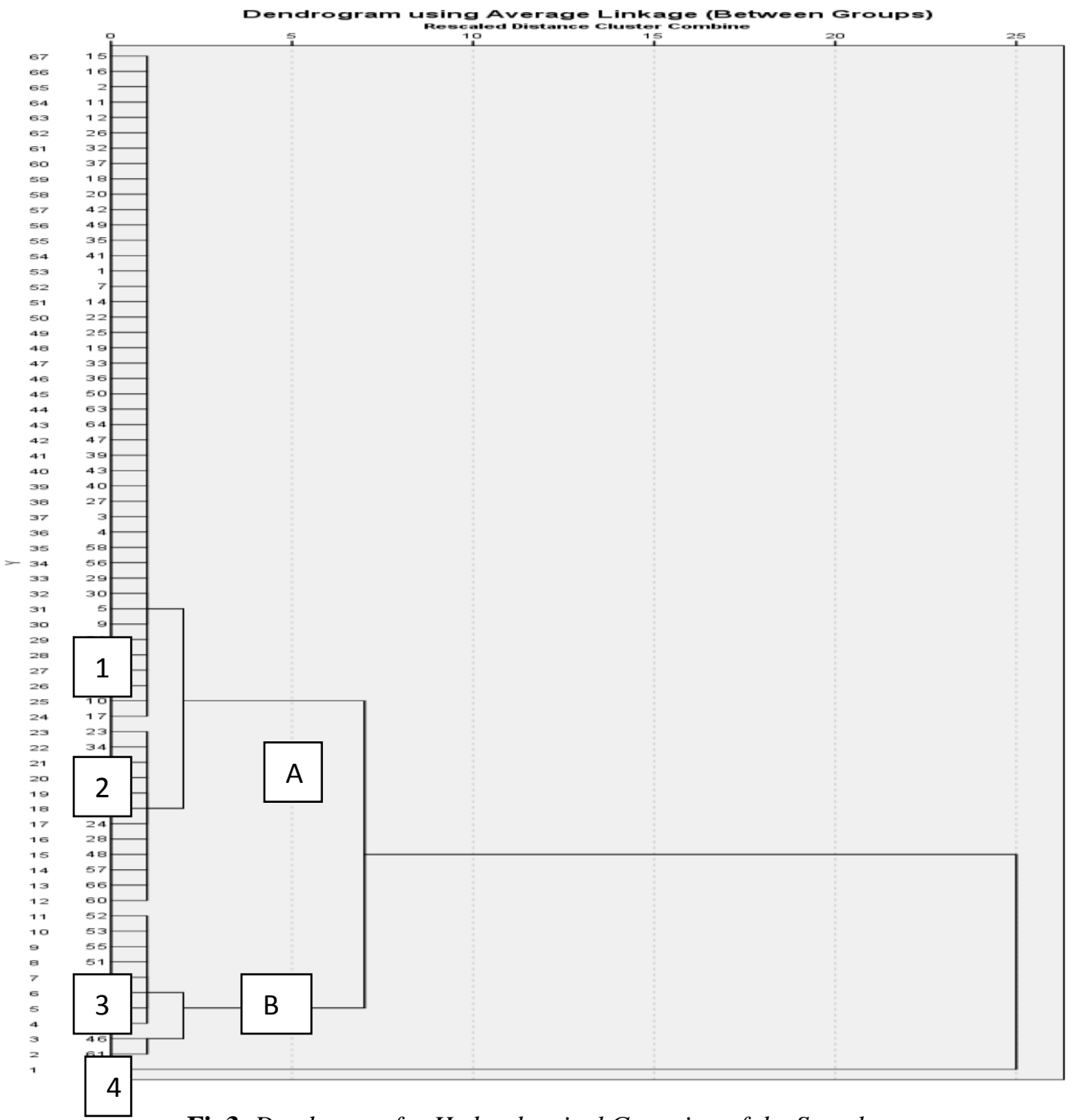

Fig3. Dendogram for Hydrochemical Grouping of the Samples

Table2. Total Variance and Eigen Values of Principle Components

\begin{tabular}{|c|c|c|c|c|c|c|c|c|c|c|c|}
\hline \multicolumn{3}{|c|}{ Initial Eigenvalues } & \multicolumn{3}{|c|}{$\begin{array}{l}\text { Extraction Sums of } \\
\text { Squared Loadings }\end{array}$} & \multicolumn{3}{|c|}{$\begin{array}{l}\text { Rotation Sums of } \\
\text { Squared Loadings }\end{array}$} & & \multicolumn{2}{|c|}{$\begin{array}{c}\text { Component } \\
\text { s }\end{array}$} \\
\hline Total & $\begin{array}{c}\% \text { of } \\
\text { Varianc } \\
\mathrm{e}\end{array}$ & $\begin{array}{c}\text { Cumulativ } \\
\text { e } \%\end{array}$ & Total & $\begin{array}{c}\% \text { of } \\
\text { Varianc } \\
\mathrm{e}\end{array}$ & $\begin{array}{c}\text { Cumulativ } \\
\text { e } \%\end{array}$ & Total & $\begin{array}{c}\% \text { of } \\
\text { Varianc } \\
\mathrm{e}\end{array}$ & $\begin{array}{c}\text { Cumulativ } \\
\text { e } \%\end{array}$ & & 1 & 2 \\
\hline $\begin{array}{c}6.37 \\
3\end{array}$ & 70.811 & 70.811 & $\begin{array}{c}6.37 \\
3\end{array}$ & 70.811 & 70.811 & $\begin{array}{c}6.32 \\
4\end{array}$ & 70.267 & 70.267 & EC & .987 & .081 \\
\hline $\begin{array}{c}1.06 \\
1\end{array}$ & 11.794 & 82.605 & $\begin{array}{c}1.06 \\
1\end{array}$ & 11.794 & 82.605 & $\begin{array}{c}1.11 \\
0\end{array}$ & 12.338 & 82.605 & TDS & .971 & .082 \\
\hline .764 & 8.492 & 91.097 & & & & & & & $\mathbf{N a}$ & .954 & .023 \\
\hline
\end{tabular}


Salinization Processes and Quality Constrains for Irrigation Water Management in Southwest El Minia, Upper Egypt.

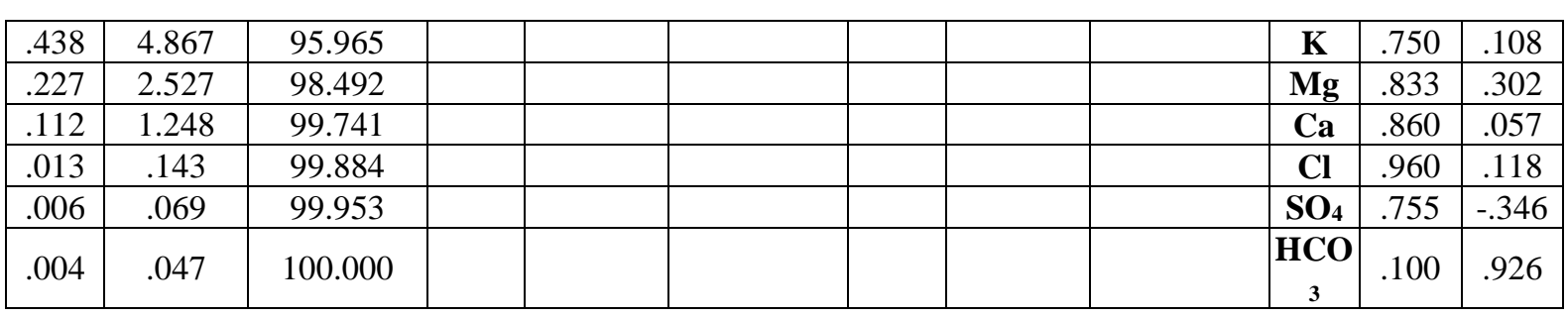

The salinization processes that might contribute to salt composition of the collected groundwater samples have been more examined using by ion /ion scatterplots and ion ratios indexes. The plot of $\mathrm{Na}$ against $\mathrm{Cl}$ (with the line 1:1 of halite dissolution), Fig. (4a) shows that the study groundwater samples follow a strong direct pattern (0.9 C.C.) reflecting halite dissolution process. The shift of few samples above 1:1 line indicates a decrease of $\mathrm{Na}$ ions that could be due to ion exchange. The plot of ( $\mathrm{Ca}+\mathrm{Mg})$ vs $\left(\mathrm{HCO}_{3}+\mathrm{SO}_{4}\right)$ Fig. (4 b) shows the samples distribution on line 1:1 reflecting $\mathrm{CO}_{3}$ dissolution (calcite, gypsum, anhydrite). The shift of some samples below the line 1:1 could be due to cation exchange which affects the $\mathrm{Ca}+\mathrm{Mg}$ relative proportion. The location of some samples points on the 1:2 line in the $(\mathrm{Na}+\mathrm{Cl})$ vs total cation relation, Fig. (4c) indicates that dissolution of rock matrix could be accompanied by silicate weathering in the processes of groundwater salinization. The ion exchange process was checked by plotting a relation between $\left(\mathrm{Ca}^{2+}+\mathrm{Mg}^{2+}-\mathrm{SO}_{4}^{-2}-\mathrm{HCO}_{3}^{-}\right)$ against $\left(\mathrm{Na}^{+}-\mathrm{Cl}^{-}\right)$, (Jankowski et al., 1998); Fig. (4d) the plotted water samples are distributed on a linear pattern of a slope equal -1 in the upper left square of the figure. This indicates that the Eocene groundwater samples are affected by ion exchange reactions between $\mathrm{Na}$ and $\mathrm{Ca}-\mathrm{Mg}$ in water and rock matrix.

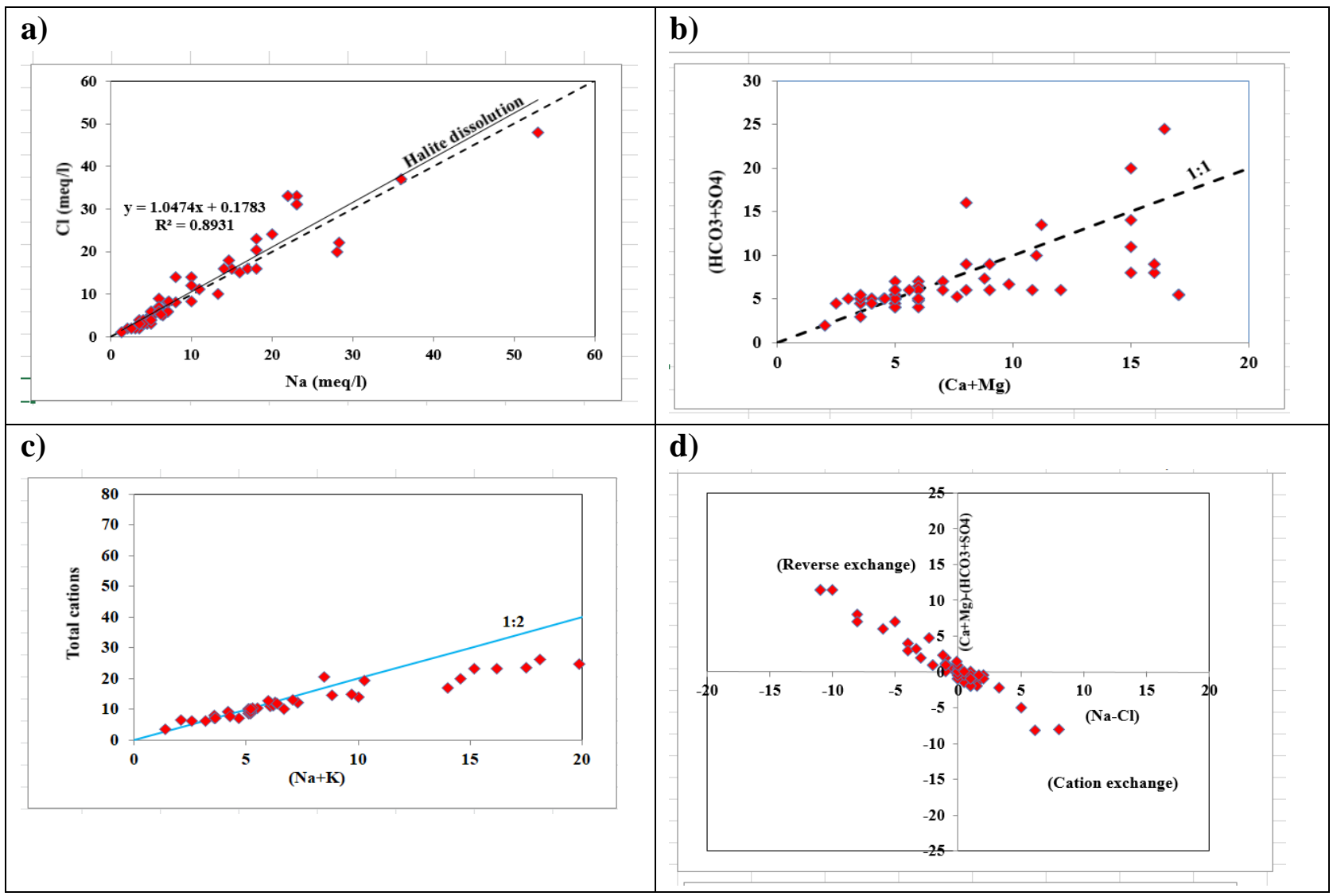

Fig4. Scatter plots of a) $\mathrm{Na}^{+}$vs. $\mathrm{Cl}^{-}$; b) $(\mathrm{Ca}+\mathrm{Mg})$ vs. $\left.\left(\mathrm{HCO}_{3}+\mathrm{SO}_{4}\right) ; c\right)(\mathrm{Na}+\mathrm{Cl})$ vs. total cations; d) (Na-Cl) vs. $(\mathrm{Ca}+\mathrm{Mg})-\left(\mathrm{HCO}_{3}+\mathrm{SO}_{4}\right)$

\subsection{Development and Application of Irrigation Water Quality Index (MCDA/AHP) approach)}

The identification of ground water quality hazards ad its suitability for irrigation use in the study area is of prime importance for socioeconomic and sustainability prospects. Apart from the several methods used for that, the present work applied the Multi Criteria Decision Approach (MCDA), Analytic Hierarchy Process (AHP) for development a new water quality index. The relevance of the 

Upper Egypt.

new index is its integrative, objective and collective nature, it combines the water quality criteria that relevantly control and complementarily express the whole irrigation water quality hazards on soils and plants. The three steps indicated in (Saaty and Vargas 2001) have been followed to conduct AHP analysis and to develop Water Quality Index (WQI) in this work, as follow:

- The first step coincides with the main objective of the decision-making problem as a hierarchical decomposition; the main goal is developing an index for evaluation irrigation water quality hazards on soil and plants and suitability of its use. To achieve this goal; eight criteria have been created covering salinity hazards, soil sodicity and permeability problems as well as specific ion toxicity. These criteria include Electrical Conductivity (EC), Sodium Adsorption Ratio (SAR), Residual sodium Carbonate (RSC), Permeability Index (PI), Magnesium Hazard (MH), Cl, Lime Deposition Potential (LDP), and Trace element toxicity of $\mathrm{Cu}, \mathrm{Cd}$, and $\mathrm{Pb}$. Each one of these criteria is subdivided into classes coinciding with the categorizing limits indicated in the corresponding standards references.

- The second step is assigning suitable weight values for the created criteria and subcriteria depicting their relative importance to irrigation suitability and hazard sensitivity. All themes and their classes were assigned weights and normalized weights based on Saaty`s AHP technique (Saaty et al, 1980). The maximum value is given to the feature with highest quality hazard potentiality and the minimum being to the lowest. Consequently, all factors are compared in pairwise matrixes, the Eigen values calculated and the normalized weights determined which represent the relative importance of one element to another. To control and test the consistency of the assigned weights and relative priorities, a consistency Ratio (CR) less than $10 \%$ (as recommended by Saaty technique) has been reached and accordingly the calculated weights become acceptable. The following equation has been used for calculating the consistency ratio:

$\mathbf{C R}=\mathbf{C I} / \mathbf{R I}$

$\mathbf{C I}=\left(\lambda_{\max }-\mathbf{n}\right) /(\mathbf{n}-\mathbf{1})$

Where, RI is the random consistency index, CI is the consistency index (1), $\mathrm{n}$ is the number of elements being compared in the matrix, $\lambda_{\max }$ is the largest or principal eigenvalue of the matrix, the tables that summarize Random Index (RI) and the comparison scale are presented in the work of Saaty, 1980. In this paper; the degree of Consistence Ratio (CR) is satisfactory, hence it is equal to 0.0066 (i.e less than the indicated limit of saaty, 1980).

- In the third step; the rating of all criteria and sub-criteria multiplied by its weight and aggregated to get local ratings with respect to each criterion, (Bhushan and Rai 2004) for the developed WQI. All criteria maps were overlaid in the GIS environment by using irrigation water quality index (IWQI). The results of analysis conducted through the described three steps of MPDA / AHP approach are given in Table ( 3) as weights and rates values calculated for the criteria and sub criteria of the developed Water Quality Index . The index is classified into five categories for irrigation water suitability, Table (4). Applying the developed index on the groundwater under study, it is found that about $28 \%$ of the samples are good to be used for irrigation purposes while most of the sample are moderate $(78 \%)$ reflecting a relatively high salinity constrains requires treatment and management to be controlled.

Table3. Calculated Weighting / Rating Values for WQI Criteria and Subclasses using MPDA/AHP Approach

\begin{tabular}{|c|c|c|c|c|c|}
\hline Goal & Categories & $\begin{array}{c}\text { Effective } \\
\text { weight of } \\
\text { criteria }\end{array}$ & $\begin{array}{c}\text { Sub- } \\
\text { Categories }\end{array}$ & $\begin{array}{l}\text { Effective weight of sub- } \\
\text { criteria }\end{array}$ & Alternative \\
\hline \multirow{7}{*}{ 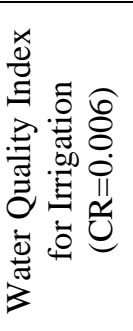 } & \multirow[t]{4}{*}{ EC } & \multirow[t]{4}{*}{0.34} & $<250$ & 0.657 & 0.223 \\
\hline & & & $250-750$ & 0.203 & 0.069 \\
\hline & & & $750-2250$ & 0.094 & 0.032 \\
\hline & & & $2250-5000$ & 0.046 & 0.016 \\
\hline & \multirow[t]{3}{*}{ RSC } & \multirow[t]{3}{*}{0.149} & $<1.25$ & 0.717 & 0.107 \\
\hline & & & $1.25-2.5$ & 0.217 & 0.032 \\
\hline & & & $>2.5$ & 0.066 & 0.010 \\
\hline
\end{tabular}


Salinization Processes and Quality Constrains for Irrigation Water Management in Southwest El Minia, Upper Egypt.

\begin{tabular}{|c|c|c|c|c|}
\hline \multirow[t]{4}{*}{ SAR } & \multirow[t]{4}{*}{0.149} & $<10$ & 0.657 & 0.098 \\
\hline & & 10 to 18 & 0.203 & 0.030 \\
\hline & & 18 to 26 & 0.094 & 0.014 \\
\hline & & $>26$ & 0.046 & 0.007 \\
\hline \multirow[t]{3}{*}{ PI } & \multirow[t]{3}{*}{0.149} & $>75$ & 0.717 & 0.107 \\
\hline & & $25-75$ & 0.217 & 0.032 \\
\hline & & $<25$ & 0.066 & 0.010 \\
\hline \multirow[t]{2}{*}{ MH } & \multirow[t]{2}{*}{0.053} & $<50$ & 0.9 & 0.048 \\
\hline & & $>50$ & 0.1 & 0.053 \\
\hline \multirow[t]{4}{*}{$\mathrm{Cl}$} & \multirow[t]{4}{*}{0.053} & $<70$ & 0.657 & 0.035 \\
\hline & & $70-140$ & 0.203 & 0.011 \\
\hline & & $141-350$ & 0.094 & 0.005 \\
\hline & & $>350$ & 0.046 & 0.002 \\
\hline \multirow[t]{4}{*}{ LDP } & \multirow[t]{4}{*}{0.053} & $<2$ & 0.657 & 0.035 \\
\hline & & 2 to 3 & 0.203 & 0.011 \\
\hline & & 3 to 4 & 0.094 & 0.005 \\
\hline & & $>4$ & 0.046 & 0.002 \\
\hline \multirow{2}{*}{$\begin{array}{c}\text { Trace } \\
\text { Element } \\
\text { Toxicity }\end{array}$} & \multirow[t]{2}{*}{0.053} & $<1$ & 0.9 & 0.048 \\
\hline & & $>1$ & 0.1 & 0.053 \\
\hline
\end{tabular}

Table4. Classification of the Developed Water Quality Index.

\begin{tabular}{|c|c|}
\hline Category & Value \\
\hline Excellent & $<0.71$ \\
\hline Good & $0.58-0.71$ \\
\hline Moderate & $0.44-0.57$ \\
\hline Unsuitable & $0.29-0.43$ \\
\hline
\end{tabular}

\subsection{Management of Irrigation Water Salinity}

The application of the developed irrigation suitability index on the collected samples reflected a significant hazards related to irrigation water salinity and quality attributes. The soil salinity degradation and potential yield reduction on typical crops in the study area have been described in the next section, also, the leaching of soil salinity for management of irrigation water quality.

\section{Crop Tolerance to salinity}

Continuous irrigation with highly saline water causes accumulation of salts in soils zones. The high soil salinity affects osmotic pressure and ability of plants roots to extract water, also may decrease infiltration if salinity is of high sodicity in addition to specific ions toxicity. The plant yield is considerably reduced under these effects. The different crops can tolerate high salinity of irrigation water and soil water (without yield reduction) up to certain threshold values specific to each crop, exceeding the threshold values of salinity causes a reduction of yield in a constant rate related to exceeding salinity, (Ayers, 1977) . Comparing the groundwater salinity of the collected samples with the work of Ayers (1977) the percentage of groundwater samples which have high salinity enough to cause $10 \%, 25 \%$ and $50 \%$ reduction of typical crops in the study area, (Onion, Dry Beans, Corn, Potato and Alfalfa, Barley and Wheat) are given in Table (5) . Obviously wheat and pearly are considered the best crops that can be cultivated in the study area using the groundwater without a proper treatment.

Table5. Percentage of Groundwater Samples of Salinity Causing 10\%, 25\% and 50\% Yield Reduction of Typical Crops in the Study Area, According to (Ayers, 1977).

\begin{tabular}{|c|c|c|c|c|c|c|c|}
\hline Item & Barley & Wheat & alfalfa & Potato & Corn & Onion & Dry beans \\
\hline $10 \%$ & $1.5 \%$ & $2 \%$ & $24 \%$ & $24 \%$ & $24 \%$ & $45 \%$ & $\mathbf{3 4 \%}$ \\
\hline $25 \%$ & & $1.5 \%$ & $12 \%$ & $12 \%$ & $12 \%$ & $\mathbf{2 0 \%}$ & $\mathbf{1 9 \%}$ \\
\hline $50 \%$ & & & $3 \%$ & $12 \%$ & $12 \%$ & $15 \%$ & $19 \%$ \\
\hline
\end{tabular}


Salinization Processes and Quality Constrains for Irrigation Water Management in Southwest El Minia, Upper Egypt.

\section{$>\quad$ Leaching of Soil Salinity -Leaching Fraction (LF) \& Leaching Requirements (LR)-}

Where salinity is a hazard in irrigation water, the only economical means of salt control is to ensure a net downward flow of water through the crop root zone and drainage over time. In this case, the normally defined net irrigation water requirement must be expanded to include an additional increment of water for leaching. The leaching requirement is the minimum fraction of the total applied and infiltrated water (irrigation plus precipitation) that must pass through the crop root zone to prevent a reduction in yield from excessive accumulation of salts . Leaching occurs whenever the infiltrating part of the irrigation and rainfall exceeds the crop evapotranspiration and the water storage capacity of the soil. In humid regions precipitation is normally sufficient to adequately flush salts from the crop root zone. In arid regions as in our case, additional irrigation water must be applied to assure adequate leaching fraction. Depending upon the degree of salinity control required, leaching may occur continuously or intermittently at intervals of a few months to a few years. Hence applying a leaching fraction requires careful management to assure efficient drainage to flush salts out of the soil zone without affecting groundwater salinity or ties of water table. The amount of water required for leaching is termed Leaching Requirement (LR), it is calculated using equation (3) which is described by (Ayers and Westcot 1985).

\section{$\mathbf{L R}=\mathbf{E C w} /(5 \mathrm{ECe}-\mathrm{ECw}) \ldots \ldots . .$.}

Where, $\mathrm{LR}=$ leaching requirement ratio, $\mathrm{ECw}=\mathrm{EC}$ of the irrigation water $(\mathrm{dS} / \mathrm{m}), \mathrm{ECe}$ is estimated $\mathrm{EC}$ of the average saturation extract of the soil root-zone profile for given crop's at a maximum yield potential $(\mathrm{dS} / \mathrm{m})$ as presented by Ayers and Westcott (1985). As the salinity of irrigation water increases, the reduction of crop yield increases and the extra water required for leaching salts increases, this stresses the availability of water resources (particularly in arid areas as the one under study which use groundwater for irrigation) and may cause drainage problems in the root zone. Considering these constrains, the salinity leaching approach has been suggested and applied here in this work (only for conditions of 10\% crop yield reductions); other ways are recommended for crop reductions $>10 \%$ (such as blending or altering the sequence of higher salinity crops as best possible cropping pattern). The salinity values of the groundwater samples that cause $10 \%$ reduction of typical crops in the study area and the soil salinity threshold values of zero \% yield reduction of these crops were applied in equation (1) to calculate the leaching requirements. The following Table (6), summarize the calculated value of the leaching requirements ratio.

Table6. Statistical Values for Leaching Requirements of 10\% Yield Reduction in the study area

\begin{tabular}{|c|c|c|c|c|c|c|c|}
\hline Item & Barley & Wheat & Alfalfa & Potato & Corn & Onion & Dry Beans \\
\hline Max. & 0.35 & 0.34 & 0.78 & 0.67 & 0.67 & 0.60 & 0.61 \\
\hline Min. & 0.35 & 0.34 & 0.26 & 0.25 & 0.25 & 0.27 & 0.25 \\
\hline Av. & 0.35 & 0.34 & 0.49 & 0.37 & 0.37 & 0.37 & 0.42 \\
\hline
\end{tabular}

The total amount of water required for irrigation of a specific crop (WQ) will sum the values required for crop growth (Evapotranspiration ET) and that required for leaching (Leaching Requirement LR). This has been calculated using equation (2), where LR is determined in this work and ET extracted from Agriculture Economic Bulletin (2009), the results given in Table (7).

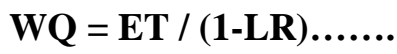

Table7. The Total Amount of Water Required ( $m^{3} /$ Fadden) for Irrigation of Specific Crops (WQ) in the study area

\begin{tabular}{|c|c|c|c|c|}
\hline Item & Barley & Wheat & Potato & Dry Beans \\
\hline Max. WQ & 1773.846 & 2339.394 & 6245.455 & 2935 \\
\hline Min. WQ & 1773.846 & 2339.394 & 2748 & 2874.25 \\
\hline Av. WQ & 1773.846 & 2339.394 & 3271.429 & 2874.42 \\
\hline
\end{tabular}

\section{CONCLUSION}

The present work introduces a hydrochemical characterization, source of salinity evaluation and hazards of water quality on irrigation as well as management of salinization of the groundwater of Eocene aquifer in west El Minia Governorate, Upper Egypt, the results of major ions of 67 groundwater samples have been used for that. The salinity ranges from 185 to $5160 \mathrm{mg} / \mathrm{l}$ with a mean value of $1216 \mathrm{mg} / \mathrm{l}$. About $74 \%$ of the samples are classified as slightly saline, $27 \%$ are classified as 
moderately saline and $9 \%$ as fresh water. The relative abundance of cations is $\mathrm{Na}>\mathrm{Mg}>\mathrm{Ca}>\mathrm{K}$ for all collected samples, $\mathrm{Cl}>\mathrm{HCO}_{3}>\mathrm{SO}_{4}$ in $81 \%$ and $\mathrm{HCO}_{3}>\mathrm{Cl}>\mathrm{SO}_{4}$ in $19 \%$ for anions dominance. Multivariate analysis of the data of this study was performed through Ionic and TDS Correlation Coefficient Matrix, Hierarchical cluster Analysis (HCA) and Principal Components Analysis (PCA) techniques using SPSS.22 software. The hydrochemical facies and salinity evolution indicate that rock/water interaction processes (leaching, dissolution, ion exchange...) are major causes of salinity in the study area. The Analytic Hierarchy Process (AHP) which is one of the Multi Criteria Decision Approach (MCDA) methods have been used for development and application of a new irrigation water quality index in this work; it has been revealed that most of the sample (about 78\%) are of relatively high salinity constrains for irrigation uses and requires salinity management and control. Based on the potential yield reduction on the typical crops in El Minia, only wheat and pearly are considered the best crops that can be cultivated in the study area using the groundwater without treatment. The irrigation water required for salinity management by leaching have been calculated in this work and added to that needed for plant evapotranspiration, the results are overall sum of water requirement should be secured for planting in the study area. This information is important for decision makers to protect the resources and /or treat them for sustainable development.

\section{ACKNOWLEDGEMENTS}

It is a pleasure to acknowledge the support provided by Egyptian Nuclear and Radiological Regulatory Authority (ENNRA) as well as the International Atomic Energy Agency, (Isotope Hydrology Section and Research Contract Administration Section)

\section{FUNDING}

This work was financially supported by IAEA Coordinated Research Project (CRP) no F33025, 20182021

\section{REFERENCES}

[1] Jakeman A. J., Barreteau, O., Hunt R. J., Rinaudo J.D., Ross A., (2016). Integrated Groundwater Management Concepts, Approaches and Challenges, Springer Nature. DOI 10.1007/978-3-319-235769_29.

[2] Sadek, M., Hagagg K., Rayan R.A., (2020a). Renewability and Usability of the Groundwater Resources in Western El Minia, Upper Egypt. IOSR Journal of Applied Chemistry (IOSR-JAC), 13(10): pp 20-29.

[3] Korany, E., Sakr S., Darwish, M., and Morsy, S. (2008). Hydrogeologic modeling for the assessment of continuous rise of groundwater levels in the quaternary aquifer, Nile valley, Egypt: case study. Intern. Conf. Geol. Arab World (GAW8), Cairo University, P. 703-711.

[4] Said, R. (1990): The geology of Egypt. Balkema, 734p.

[5] RIGW, Research Institute for Groundwater (1992) Hydrogeological Map of Egypt, Scale 1:100,000. 2nd Edition, Map Sheet of El-Minia.

[6] Tantawi, M. (2006). Isotopic and hydrochemical application to the surface and groundwater assessment in El Minia district, Egypt. Ph.D. Fac of Sci, El Minia University.

[7] Abou Heleika, M., and Niesner, E. (2008). Configuration of the limestone aquifers in the central part of Egypt using electrical measurements. Hydrogeology Journal, Vol. 17, No. 2, pp. 433-446, 2009.

[8] El Kashouty M., El Sayed E and Kamel A. A., (2013). The hydrochemical characteristics and evolution of groundwater and surface water in the western part of the River Nile, El Minia district, Upper Egypt, Arab J Geosci 6:55-76.

[9] Abdulaziz M. Abdulaziz, Abdalla M. Faid , M. Abdulaziz, A. M. Faid, (2017). Aquifer Characterization and Groundwater Potential Using Integrated Geoelectrical Sounding and Geoinformatics in West Maghagha Area, Minia Governorate, Egypt Journal of Geology, , 7, 1625-1643. http://www.scirp.org/journal/ojg

[10] Reda G. M. Ibrahim, Lyons W. B., (2017). Assessment of the Hydrogeochemical Processes Affecting Groundwater Quality in the Eocene Limestone Aquifer at the Desert Fringes of El Minia Governorate, Egypt Aqua Geochem 23:33-52.DOI 10.1007/s10498-016-9298.

[11] Sallam F. T., Sadek M.A., Rayan R. A., El-Shahat M.F., (2020) Sources of Salinity and Suitability for Irrigation and Drinking Use of the Groundwater of Northwest of El Minia, Upper Egypt. Egypt. J. Chem. Vol. 63, No. 10 pp. 4063 - 4074. http://ejchem.journals.ekb.eg/.

[12]Zavadskas E. K \& Turskis Z. (2011), Multiple criteria decision making (MCDM) methods in economics: an overview, Technological and Economic Development of Economy, 17:2, 397-427.DOI: 10.3846/20294913.2011.593291. 

Upper Egypt.

[13] Sadek, M.A., Hagagg, K., (2020b). A Novel Groundwater Sustainability Index using AHP/GIS Approach, International Journal of Research in Environmental Science (IJRES), Volume 6, Issue 4, 2020, PP 28-40. ISSN No. (Online) 2454-9444.1DOI: http://dx.doi.org/10.20431/2454-9444.0604003.

[14] Conoco (1987): Geological Map of Egypt, Scale 1:500,000. Luxor Sheet, the General Petroleum Company, Cairo.

[15] Kamel AK (2012). Hydrochemical evaluation of the water resources in Minia district, Egypt. M.Sc. Thesis, Geology Department, Faculty of Science, Minia University, p.1-16.

[16] ASTM D3977-97(2002), Standard Test Methods for Determining Sediment Concentration in Water Samples, ASTM International, West Conshohocken, PA, 1997. DOI: 10.1520/D3977-97R02.

[17] Hem JD (1991) Study and interpretation of the chemical characteristics of natural water. $3^{\text {rd }}$ ed. scientific publication Jodhbur, India 2254.

[18] Saaty, T.L. (1980). The Analytic Hierarchy Process; McGraw-Hill: New York, NY, USA.

[19] ASHLEY, R.P. and LLOYD, J.W. (1978). An example of the use of factor analysis and cluster analysis in groundwater chemistry interpretation. Jour. Hydrology, v.39, pp.355-364.

[20] Jankowski, J., Acworth, R.I. and Shekarforoush, S. (1998). Reverse Ion Exchange in a Deeply Weathered Porphyritic Dacite Fractured Aquifer System, Yass, New South Wales, Australia. In G. B. Arehartand J. R. Hulston (Eds), Proc. 9th Int. Symp. Water- Rock Interaction, Taupo, New Zealand, Rotterdam: Belkema, 243-246.

[21] Bhushan, N. and Rai, K. (2004) Strategic Decision Making: Applying the Analytic Hierarchy Process. Springer, Berlin, 9, 11-21. http://www.springer.com/978-1-85233-756-8.

[22] Saaty T. L. and Vargas L. G. (2001). De Logic of Priorities, RWS Publications, Pittsburgh, PA, USA.

[23] Ayers R.S. (1977), Quality of water for irrigation, jour. Of the irrig. And Drain.Div. ASCE. Vol 103. No. IR2, June 1977. P.140.

[24] Ayers, R.S., and D.W. Westcot. (1985). Water Quality for Agriculture, FAO Irrigation and Drainage Paper 29 rev 1. FAO, UN, Rome 174pp.

Citation: R. A. Hussien, et.al., "Salinization Processes and Quality Constrains for Irrigation Water Management in Southwest El Minia, Upper Egypt.", International Journal of Research in Environmental Science (IJRES), vol. 7, no. 2, pp. 1-11, 2021. Available: DOI: http://dx.doi.org/ 10.20431/24549444.0702001

Copyright: (c) 2021 Authors. This is an open-access article distributed under the terms of the Creative Commons Attribution License, which permits unrestricted use, distribution, and reproduction in any medium, provided the original author and source are credited. 